\title{
Preamplifier Device
}

National Cancer Institute

\section{Source}

National Cancer Institute. Preamplifier Device. NCI Thesaurus. Code C50116.

An electronic device designed to boost the signal of a low-level input signal to an intermediate level prior to further amplification. 